\title{
Echinochasmus caninus n. comb. (Trematoda: Echinostomatidae) Infection in Eleven Riparian People in Khammouane Province, Lao PDR
}

\author{
Jong-Yil Chai' ${ }^{1,2 *}$, Taehee Chang1', Bong-Kwang Jung', Hyejoo Shin'1, Woon-Mok Sohn³, Keeseon S. Eom4, \\ Tai-Soon Yong ${ }^{5}$, Duk-Young Min ${ }^{6}$, Bounlay Phammasack ${ }^{7}$, Bounnaloth Insisiengmay ${ }^{7}$, Han-Jong Rim ${ }^{8}$ \\ 1'Institute of Parasitic Diseases, Korea Association of Health Promotion, Seoul 07649, Korea; '2Department of Tropical Medicine and Parasitology, \\ Seoul National University College of Medicine, Seoul 03080, Korea; ${ }^{3}$ Department of Parasitology and Tropical Medicine, and Institute of Health \\ Sciences, Gyeongsang National University College of Medicine, Jinju 52727, Korea; ${ }^{4}$ Department of Parasitology and Parasite Research Center, \\ Parasite Resource Bank, Chungbuk National University School of Medicine, Cheongju 28644, Korea; ${ }^{5}$ Department of Environmental Medical \\ Biology, Institute of Tropical Medicine and Arthropods of Medical Importance Resource Bank, Yonsei University College of Medicine, Seoul 03722, \\ Korea; ${ }^{6}$ Department of Microbiology and Immunology, Eulji University School of Medicine, Daejeon 34824, Korea; ${ }^{7}$ Department of Hygiene and \\ Prevention, Ministry of Health, Vientiane, Lao PDR; ${ }^{8}$ Department of Parasitology, Korea University College of Medicine, Seoul 02841, Korea
}

\begin{abstract}
Adult specimens of Echinochasmus caninus n. comb. (Verma, 1935) (Trematoda: Echinostomatidae) (syn. Episthmium caninum Yamaguti, 1958) were recovered from 11 riparian people who resided along the Mekong River in Khammouane Province, Lao PDR. In fecal examinations done by the Kato-Katz technique, the cases revealed eggs of Opisthorchis viverrini/minute intestinal flukes, hookworms, and in 2 cases echinostome eggs. To recover the adult helminths, praziquantel $30-40 \mathrm{mg} / \mathrm{kg}$ and pyrantel pamoate $10-15 \mathrm{mg} / \mathrm{kg}$ in a single dose were given and purged with magnesium salts. Various species of trematodes (including O. viverrini and Haplorchis spp.), cestodes, and nematodes were recovered from their diarrheic stools. Among the trematodes, small echinostome flukes $(n=42 ;$ av. 3.8 specimens per case) of 0.7-1.2 mm in length are subjected in this study. They are morphologically characterized by having 24 collar spines interrupted dorsally and anterior extension of vitellaria from the cirrus sac or genital pore level to the posterior end of the body. Particularly based on this extensive distribution of vitellaria, the specific diagnosis was made as Echinochasmus caninus. The cases were co-infected with various other helminth parasites; thus, clinical manifestations specific for this echinostome infection were difficult to determine. The present paper describes for the first time human $E$. caninus infections in Lao PDR. Our cases marked the 4-14th human infections with this echinostome around the world following the 3 previous cases reported from Thailand.
\end{abstract}

Key words: Echinchasmus caninus (syn. Episthmium caninum), echinostome, Khammouane Province, Lao PDR

Echinostomes (the family Echinostomatidae) are most harmful among the zoonotic human intestinal flukes $[1,2]$. They can cause severe gastrointestinal symptoms, including epigastric or abdominal pain accompanied by diarrhea, easy fatigue, malnutrition, and sometimes ulcer and bleeding [1,2]. In particular, heavy worm loads of Artyfechinostomum spp. infection may lead even to death of humans and pigs due to marked malnutrition, anemia, and intestinal perforation $[3,4]$. A total of 23 echinostome species worldwide which belong to

\footnotetext{
- Received 29 April 2019, revised 15 June 2019, accepted 15 June 2019.

*Corresponding author (cjy@snu.ac.kr)

(C) 2019. Korean Society for Parasitology and Tropical Medicine

This is an Open Access article distributed under the terms of the Creative Commons

Attribution Non-Commercial License (http://creativecommons.org/licenses/by-nc/4.0) which permits unrestricted non-commercial use, distribution, and reproduction in any

medium, provided the original work is properly cited.
}

Echinostoma, Isthmiophora, Echinochasmus, Acanthoparyphium, Artyfechinostomum, Echinoparyphium, Himasthla, and Hypoderaeum genera are currently known to infect humans $[1,2]$.

In Lao People's Democratic Republic (Lao PDR), foodborne trematodes, such as Opisthorchis viverrini, Haplorchis spp. (H. taichui, H. pumilio, and H. yokogawai), and lecithodendriid-like flukes (Phaneropsolus bonnei and Caprimolgorchis molenkampi) are common together with soil-transmitted nematodes, including hookworms [5-13]. With regard to echinostomes, only 3 reports have been available. The first was Echinochasmus japonicus infection in 3 people in Savannakhet Province [14]. The second was echinostome fluke (Echinostoma revolutum, Artyfechinostomum malayanum, E. japonicus, and Euparyphium sp.) infections among the residents of Khammouane Province [8]. The third was 2 human infections with Echinostoma ilocanum 
in Savannakhet Province [15]. We recently confirmed 11 human cases infected with Echinochasmus caninus n. comb. (syn. Episthmium caninum Yamaguti, 1958) in riparian villages along the Mekong River in Khammouane Province, Lao PDR. These 11 cases included 7 previous cases reported erroneously under the name E. japonicus infection [8] which are here revised as $E$. caninus infection.

The Korea Association of Health Promotion, Seoul, Korea, and the Department of Hygiene and Prevention, Ministry of Health, Lao PDR conducted a collaborative project to control intestinal helminthiases in Lao PDR (2000-2004 and 20072011). During this project, we conducted fecal surveys using the Kato-Katz technique in 5 localities of Khammouane Province (Nong Bone, Mahaxay, Phova, Bone Som, and Thongmay villages) in March 2003 and June 2009, 2 times. We tried to collect adult flukes after anthelmintic treatment followed by purging and finally detected 11 cases infected with E. caninus.

The procedure of worm collection was as described previously [6-10]. Briefly, the egg-positive cases of O. viverrini/minute intestinal flukes, or echinostomes, were given orally 30-40 mg/kg praziquantel (Shinpoong Pharm. Co., Seoul, Korea) and $10-15 \mathrm{mg} / \mathrm{kg}$ of pyrantel pamoate (Hangzhou Minsheng Pharm. Group, Hangzhou, China) in a single dose and purged with 20-30 $\mathrm{g} \mathrm{MgSO}_{4}$ an hour later. Adult flukes were collected from the diarrheic stools and washed several times in water. They were fixed in $10 \%$ formalin under a cover slip pressure, stained with acetocarmine, and morphologically examined. Fecal examination of the village residents and worm recovery from the 11 cases were officially and ethically approved by the
Ministry of Health, Lao PDR, under the agreement of the Korea-Laos International Collaboration on Intestinal Parasite Control in Lao PDR (2000-2004 and 2007-2011). The worm recovery was performed after obtaining informed consent from each person.

A total of 42 specimens of E. caninus were recovered from the 11 people (Table 1). The cases were 21-46 years of age, consisting of 6 men and 5 women, and the worm load was relatively low, from 1 to 21 specimens per case. Some people complained of variable degrees of abdominal pain, epigastric pain, and indigestion. However, they appeared to be co-infected with other helminth parasites, such as O. viverrini, Haplorchis spp., lecithodendriid-like flukes, hookworms, whipworms, pinworms, and Taenia species (reported in $[7,8]$ ). Therefore, specific symptoms due to $E$. caninus infection was difficult to determine.

Adult flukes of E. caninus were leaf-like, plump, or slightly elongated (Fig. 1A, B), being averaged $0.99(0.67-1.18) \mathrm{mm}$ in length and $0.36(0.27-0.45) \mathrm{mm}$ in width $(\mathrm{n}=10)$ (Table 2). The anterior and posterior ends were attenuated, and the anterior end showed the characteristic features of an echinostome fluke, equipped with a head collar and collar spines around the oral sucker (Fig. 1A-D). The number of collar spines was 24 in total, 12 on each side, interrupted dorsally on the oral sucker, arranged in a single row for the dorsal spines ( 2 dorsal spines on each side overlapping the oral sucker) and 2 alternating rows for the lateral and ventral ones (Fig. 1C, D). The collar spines were relatively long $(0.032-0.045 \mathrm{~mm})$ and broad (1/3 of the length), larger for the dorsal spines and slightly

Table 1. Recovery of Echinochasmus caninus specimens from villagers in Khammouane Province, Lao PDR

\begin{tabular}{|c|c|c|c|c|c|}
\hline Villager no. ${ }^{a}$ & Age & Sex & Village name & Year surveyed & No. of worms recovered \\
\hline 1 & 42 & $\mathrm{~F}$ & Nong Bone & 2003 & $21^{c}$ \\
\hline 2 & 21 & $M$ & Mahaxay & 2009 & 8 \\
\hline 3 & 30 & $\mathrm{~F}$ & Nong Bone & 2003 & $4^{c}$ \\
\hline 4 & 32 & $M$ & Nong Bone & 2003 & $2^{c}$ \\
\hline 5 & 34 & M & Nong Bone & 2003 & $1^{c}$ \\
\hline 6 & 43 & $M$ & Nong Bone & 2003 & $1^{c}$ \\
\hline 7 & 25 & M & Phova & 2003 & $1^{\mathrm{c}}$ \\
\hline 8 & 40 & $\mathrm{~F}$ & Phova & 2003 & $1^{c}$ \\
\hline 9 & 46 & $\mathrm{~F}$ & Bone Som & 2009 & 1 \\
\hline 10 & 45 & $F$ & Bone Som & 2009 & 1 \\
\hline 11 & 30 & $\mathrm{M}$ & Thongmay & 2009 & 1 \\
\hline Total & & & & & 42 \\
\hline
\end{tabular}

aSome villagers complained of gastrointestinal symptoms of variable degrees, including abdominal pain, epigastric pain, and indigestion. 'Other helminth parasites recovered included Opisthorchis viverrini, Haplorchis spp., lecithodendriid-like flukes, hookworms, Trichuris trichiura, Trichostrongylus sp., Enterobius vermicularis, Taenia sp., Echinostoma revolutum, Artyfechinostomum malayanum, and Euparyphium sp. [7,8].

`These specimens were reported erroneously as Echinochasmus japonicus in our previous report [8]. 
A

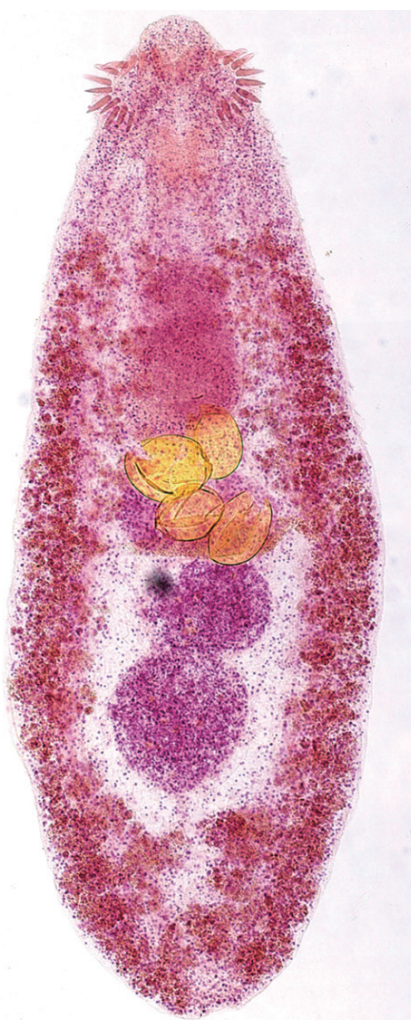

B

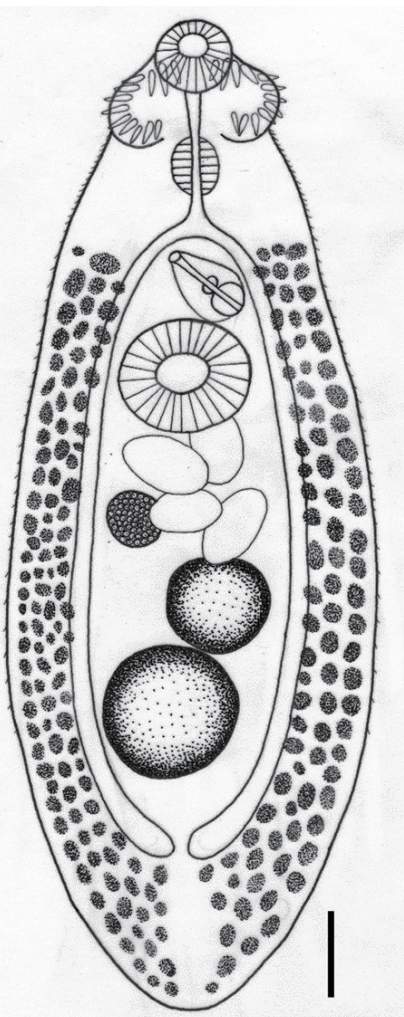

c
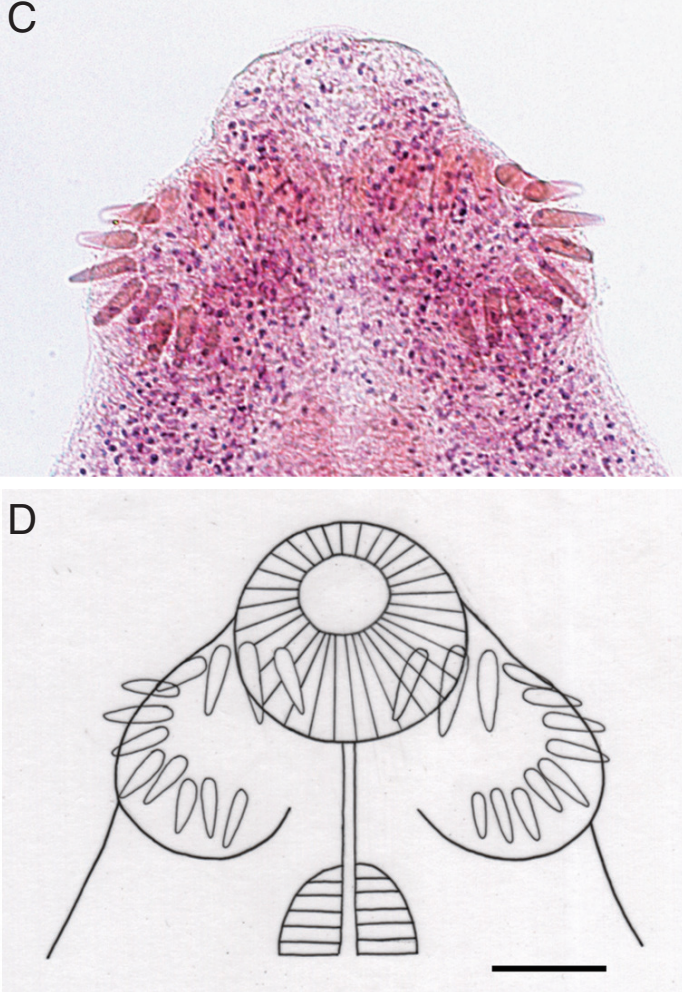

Fig. 1. Adult specimens of Echinochasmus caninus n. comb. (syn. Episthmium caninum) recovered from riparian residents in Khammouane Province, Lao PDR. (A) Adult E. caninus specimen (1.0 mm long and $0.37 \mathrm{~mm}$ wide) showing its most characteristic feature for differentiation from other species of Echinochasmus, i.e., the extensive distribution of the vitellaria from the level of the cirrus sac or genital pore to the posterior end of the body. The head collar, collar spines, uterine eggs $(n=4)$, ovary, and 2 tandem testes are also characteristically seen. Semichon's acetocarmine stained. (B) Line drawing of the specimen in Fig. 1A. Scale bar $=90 \mu \mathrm{m}$. (C) The head collar bearing 24 collar spines interrupted dorsally, 12 on each side, in a single row in dorsal spines and 2 alternative rows in lateral and ventral ones. The dorsal spines are a little larger than the lateral and ventral ones. (D) Line drawing of the head collar and collar spines in Fig. $1 \mathrm{C}$. Scale bar $=50 \mu \mathrm{m}$.

Table 2. Measurements of Echinochasmus caninus adult specimens recovered from riparian people in Khammouane Province, Lao PDR in comparison with those in a previous report

\begin{tabular}{|c|c|c|}
\hline \multirow{2}{*}{ Item } & \multicolumn{2}{|c|}{ Measurements in mm } \\
\hline & The present study $(n=10)$ (mean) & Verma [16] $(n=3)$ \\
\hline Body & $0.67-1.18(0.99) \times 0.27-0.45(0.36)$ & $0.88-1.21 \times 0.36-0.46$ \\
\hline Head collar & $0.096-0.15(0.12) \times 0.15-0.20(0.18)$ & $0.13-0.17 \times 0.20-0.22$ \\
\hline No. collar spines & 24 & 24 \\
\hline Oral sucker & $0.053-0.091(0.076) \times 0.068-0.096(0.080)$ & $0.060-0.076 \times 0.070-0.084$ \\
\hline Pharynx & $0.052-0.081(0.067) \times 0.042-0.078(0.056)$ & $0.050-0.076 \times 0.050-0.067$ \\
\hline Esophagus (length) & $0.11-0.23$ & $0.050-0.11$ \\
\hline Cirrus sac & $0.057-0.17(0.11) \times 0.054-0.12(0.093)$ & $0.10-0.13 \times 0.084-0.09$ \\
\hline Ventral sucker & $0.076-0.16(0.13) \times 0.084-0.18(0.16)$ & $0.11-0.12 \times 0.13-0.14$ \\
\hline Ovary & $0.057-0.19(0.098) \times 0.047-0.15(0.084)$ & $0.09-0.13 \times 0.07-0.084$ \\
\hline Anterior testes & $0.058-0.15(0.10) \times 0.094-0.21(0.15)$ & $0.13 \times 0.084-0.11$ \\
\hline Posterior testes & $0.083-0.17(0.12) \times 0.057-0.17(0.13)$ & $0.05-0.24 \times 0.14-0.19$ \\
\hline No. of uterine eggs & $1-4$ & $0-3$ \\
\hline Size of uterine eggs & $0.084-0.121(0.098) \times 0.066-0.080(0.068)$ & $0.084 \times 0.05-0.06$ \\
\hline
\end{tabular}


smaller for ventral spines, with sharply pointed ends (Fig. 1C, D). The oral sucker was small and about a half the size of the ventral sucker. The cirrus sac containing the seminal vesicle and ejaculatory duct was located near the anterior edge of the ventral sucker but sometimes passed posteriorly toward the middle level of the ventral sucker. The uterine tubule was broad but short only with a few number of eggs, 1-4 (mean; $2.7)$ per specimen. The ovary was usually submedian and rarely median. The distribution of the vitellaria was extensive; they extended laterally from the level of the intestinal bifurcation near the cirrus sac or genital pore down to the posterior end of the body. These 2 lateral groups of vitellaria merged near the posterior end of the body. Two testes were tandem in the posterior field of the body; their shape was almost round or elliptical without any lobulations. The eggs in the uterus were large and oval, with a relatively narrow operculum and small abopercular wrinkles at the posterior end; they measured 98 (84-121) $\mu \mathrm{m}$ long and 68 (66-80) $\mu \mathrm{m}$ wide $(\mathrm{n}=20)$. All these morphological characters were compatible with previous descriptions of E. caninus [16-18].

The genus Episthmium was erected by Lühe in 1909 using Episthmium africanum (Stiles, 1901) as the type, including another species Episthmium bursicola (Braun, 1901) [19]. However, the genus Episthmium was rejected by Odhner in 1910 and the 2 species were renamed as Echinochasmus africanum and Echinochasmus bursicola, respectively [19]. Later, Episthochasmus caninum Verma, 1935 was reported as a new taxon from dogs in Calcutta, India [16]. In 1958, Yamaguti [20] renamed this echinostome parasite as Episthmium caninum synonymizing Episthochasmus Verma, 1935 with Episthmium Lühe, 1909. Thereafter, the name Episthmium caninum had been used for a considerably long time until 2005. In the meantime, 3 human infections with this fluke were first found in Thailand which were reported in 2 papers, 1985 [17] and 1991 [18]. However, in 2001, Kostadinova and Gibson [19] suggested that Episthmium may be a synonym of Echinochasmus, accepting the Odhner's opinion, and subsequently, in 2005, Kostadinova [21] synonymized the genus Episthmium with Echinochasmus. Following this taxonomic move, in the present report, the name Episthmium caninum has been changed into Echinochasmus caninus as a new combination.

The present specimens of $E$. caninus most closely resembled E. japonicus and Echinochasmus liliputanus. However, they differed from these 2 and also from other species of Echinochasmus in that the former (under the name Episthmium caninum) has a profusely developed and extensively distributed vitellaria into the forebody, whereas in other species of Echinochasmus the extent of the vitellaria in the forebody is considerably limited [20]. The size, shape, and arrangement of the collar spines are also characteristic by different species of Echinochasmus. In our specimens of $E$. caninus, the collar spines were relatively large (larger in dorsal spines and smaller in ventral ones), broad, and sharply pointed, with 6 dorsal spines arranged in a single row and 6 lateral and ventral ones arranged in a double row on each side. In addition, in E. caninus, 2 dorsal spines on each side were overlapped with the oral sucker [16]. In E. japonicus, the collar spines were similar in size with our specimens; however, they were arranged in a double row both in dorsal as well as in lateral and ventral spines [22]. Only 1 dorsal spine on each side was overlapped with the oral sucker in $E$. japonicus [22], whereas 2 dorsal ones on each side were overlapped with the oral sucker in most of our specimens. The collar spines of $E$. japonicus were almost uniform in size and slender with sharp-pointed ends [22] but those of our specimens differed in size between the dorsal and ventral ones and were relatively broad with sharp-pointed ends. E. liliputanus had a larger body size than E. caninus and smaller collar spines arranged simply in a single row [22].

Echinostome infections are foodborne but have been neglected because there is no much information about this group of parasites $[1,2,15]$. However, human echinostomiasis is not uncommon in endemic localities, particularly in Southeast Asia and the Far East $[1,2,15]$. In addition, microscopists may overlook or misinterpret echinostome eggs as other kinds of eggs or even artifacts particularly in routine Kato-Katz fecal smear examinations $[1,2,15]$. Moreover, eggs of different echinostome species closely resemble one another, and thus, for a specific diagnosis, adult worms should be recovered from each case and identified morphologically or molecularly [15].

In Lao PDR, with the exception of the following 3 reports, i.e., E. japonicus infection in 3 residents of Savannakhet Province [14], E. revolutum, A. malayanum, E. japonicus, and Euparyphium sp. infections in 9 people of Khammouane Province [8], and E. ilocanum infection in 2 residents of Savannakhet Province [15], no other echinostome infections have been documented from humans. In the present study, we detected 11 riparian people infected with E. caninus in Khammouane Province, Lao PDR.

Echinostome infections can cause severe clinical manifestations, particularly in cases with heavy worm loads [1-4]. How- 
ever, in our cases, the worm load was considerably low, i.e., 1-21 worms per case, and the cases were co-infected with other helminth species. Therefore, specific symptoms due to E. caninus were difficult to determine. Possible clinical manifestations that would occur in heavy E. caninus and other Echinochasmus spp. infection cases need to be determined.

Human echinostome infections can be fish-borne, snailborne, or amphibian-borne [23]. E. caninus is a fish-borne species, although the complete life cycle of E. caninus has not yet been uncovered. In Hainan Island, China, a freshwater fish, Macropodus opercularis, was reported to be the second intermediate host of this echinostome [24]. Thus, the source of human infection in 3 Thai patients was suggested to be the fish M. opercularis [25], although fish surveys were not performed in Thailand. The life cycle of $E$. caninus has never been studied in Lao PDR, and the source of infection in our cases is unclear. Studies on the life cycle of E. caninus should be investigated in the near future in Lao PDR.

In conclusion, the present study demonstrated for the first time the presence of human E. caninus infection in Lao PDR. This is the third report following the 2 dealing with 3 human cases of E. caninus infection in Thailand $[17,18]$.

\section{ACKNOWLEDGMENTS}

We thank the staff of the Center for Laboratory and Epidemiology, Department of Hygiene and Prevention, Vientiane, and Khammouane Provincial Health Department, Khammouane, Lao PDR for their help in this study. We also thank the staff of Korea Association of Health Promotion, Seoul, Korea who kindly cooperated in Korea-Laos International Collaboration on Intestinal Parasite Control in Lao PDR (20002004 and 2007-2011).

\section{CONFLICT OF INTEREST}

We have no conflict of interest related to this work.

\section{REFERENCES}

1. Chai JY. Echinostomes in humans. In Fried B, Toledo R eds, The Biology of Echinostomes. New York, USA. Springer. 2009, pp 147-183.

2. Chai JY. Echinostomes. In Xiao L, Ryan U, Feng Y eds, Biology of Foodborne Parasites. Food Microbiology Series. Boca Raton, Florida, USA. CRC Press, Taylor \& Francis Group. 2015, pp 351-
369.

3. Reddy DB, Ranganaykamma I, Venkataratnam D. Artyfechinostomum mehrai infestation in man. J Trop Med Hyg 1964; 67: 58-59.

4. Bandyopadhyay AK, Maji AK, Manna B, Bera DK, Addy M, Nandy A. Pathogenicity of Artyfechinostomum oraoni in naturally infected pigs. Trop Med Parasitol 1995; 46: 138-139.

5. Rim HJ, Chai JY, Min DY, Cho SY, Eom KS, Hong SJ, Sohn WM, Yong TS, Deodato G, Standgaard H, Phommasack B, Yun CH, Hoang EH. Prevalence of intestinal parasite infections on a national scale among primary schoolchildren in Laos. Parasitol Res 2003; 91: 267-272.

6. Chai JY, Park JH, Han ET, Guk SM, Shin EH, Lin A, Kim JL, Sohn WM, Yong TS, Eom KS, Min DY, Hwang EH, Phommasack B, Insisiengmay, Rim HJ. Mixed infections with Opisthorchis viverri$n i$ and intestinal flukes in residents of Vientiane Municipality and Saravane Province in Laos. J Helminthol 2005; 79: 283-289.

7. Chai JY, Han ET, Shin EH, Sohn WM, Yong TS, Eom KS, Min DY, Um JY, Park MS, Hoang EH, Phommasack B, Insisiengmay, Lee SH, Rim HJ. High prevalence of Haplorchis taichui, Prosthodendrium molenkampi, and other helminth infections among people in Khammouane Province, Lao PDR. Korean J Parasitol 2009; 47: 243-247.

8. Chai JY, Sohn WM, Yong TS, Eom KS, Min DY, Hoang EH, Phammasack B, Insisiengmay B, Rim HJ. Echinostome flukes recovered from humans in Khammouane Province, Lao PDR. Korean J Parasitol 2012; 50: 269-272.

9. Chai JY, Yong TS, Eom KS, Min DY, Jeon HK, Kim TY, Jung BK, Sisabath L, Insisiengmay B, Phommasack B, Rim HJ. Hyperendemicity of Haplorchis taichui infection among riparian people in Saravane and Champasak Province, Lao PDR. Korean J Parasitol 2013; 51: 305-311.

10. Chai JY, Sohn WM, Jung BK, Yong TS, Eom KS, Min DY, Insisiengmay B, Insisiengmay S, Phommasack B, Rim HJ. Intestinal helminths recovered from humans in Xieng Khouang Province, Lao PDR with a particular note on Haplorchis pumilio infection. Korean J Parasitol 2015; 53: 439-445.

11. Sayasone S, Vonghajak Y, Vanmany M, Rasphone O, Tesana S, Utzinger J, Akkhavong K, Odermatt P. Diversity of human intestinal helminthiasis in Lao PDR. Trans R Soc Trop Med Hyg 2009; 103: 247-254.

12. Sayasone S, Mak TK, Vanmany M, Rasphone O, Vounatsou P, Utzinger J, Akkhavong K, Odermatt P. Helminth and intestinal protozoa infections, multiparasitism and risk factors in Champasack province, Lao Peoples' Democratic Republic. PLoS Negl Trop Dis 2011; 5: e1037.

13. Laymanivong S, Hongvanthong B, Keokhamphavanh B, Phommasansak M, Phinmaland B, Sanpool O, Maleewong W, Intapan PM. Current status of human hookworm infections, ascariasis, trichuriasis, schistosomiasis mekongi and other trematodiases in Lao Peoples' Democratic Republic. Am J Trop Med Hyg 2014; 90: 667-669.

14. Sayasone S, Tesana S, Utzinger J, Hatz C, Akkhavong K, Odermatt $\mathrm{P}$. Rare human infection with the trematode Echinochasmus 
japonicus in Lao PDR. Parasitol Int 2009; 58: 106-109.

15. Chai JY, Sohn WM, Cho J, Eom KS, Yong TS, Min DY, Hoang EH, Phammasack B, Insisiengmay B, Rim HJ. Echinostoma ilocanum infection in two residents of Savannakhet Province, Lao PDR. Korean J Parasitol 2018; 56: 77-81.

16. Verma SC. Studies on the Indian species of the genus Echinochasmus, Part I. and on an allied new genus Episthochasmus. Proc Ind Acad Sci 1935; 1: 837-856.

17. Radomyos P, Bunnag D, Harinasuta T. Report of Episthmium caninum (Verma, 1935) Yamaguti, 1958 (Digenea: Echinostomatidae) in man. Southeast Asian J Trop Med Public Health 1985; 16: 508-511.

18. Radomyos P, Charoenlarp P, Harinasuta T. Human Episthmium caninum (Digenea: Echinostomatidae) infection: report of two more cases. J Trop Med Parasitol 1991; 14: 48-50.

19. Kostadinova A, Gibson D. A redescription of Uroproctepisthmium bursicola (Creplin, 1837) n. comb. (Digenea: Echinostomatidae), and re-evaluation of the genera Episthmium Lühe, 1909 and Uroproctepisthmium Fischthal \& Kuntz, 1976. Syst Parasitol 2001; 50: 63-67.
20. Yamaguti S. Systema Helminthum. Vol. I. The Digenetic Trematodes of Vertebrates (Part I). New York, USA. Interscience Publishers. 1958, pp 1-979.

21. Kostadinova A. Family Echinostomatidae looss, 1899. In Jones A, Bray RA, Gibson DI eds, Keys to the Trematoda. Volume. 2. London, UK. Natural History Museum. 2005, pp 9-64.

22. Chen HT, Chen S, Chu H, Zheng Z, Tang Z. Echinostomatidae dietz, 1909. In Chen HT, Fauna Sinica. Platyhelminthes. Trematoda. Digenea (I). Beijing, China. Science Press. 1985, pp 333497.

23. Yu SH, Mott KE. Epidemiology and morbidity of food-borne intestinal trematode infections. Trop Dis Bull 1994; 91: 125-152.

24. Kobayasi H. Studies on the flukes in Hainan Island. III. On the flukes belonging to the Family Echinostomatidae Odhner, 1910, Episthochasmus caninum Verma, 1935. Acta Nippon Med Trop 1942; 4: 97-105.

25. Tungtrongchitr A, Radomyos P. Human intestinal fluke infections in Thailand. Bull Chulalongkorn Med Tech 1989; 3: 417427 (in Thai). 